\section{Introducció a l'arquitectura i el projecte}

\author{
Una experiència pionera en tot l'Estat on, per primera vegada, \\ es va implantar l'ensenyament dels projectes arquitectònics en \\ el primer curs de la carrera
}

\section{Pere Riera}

Recibido 2017.01.26 ::.: Aceptado 2017.01.27 DOI: 10.5821/palimpsesto.16.5167

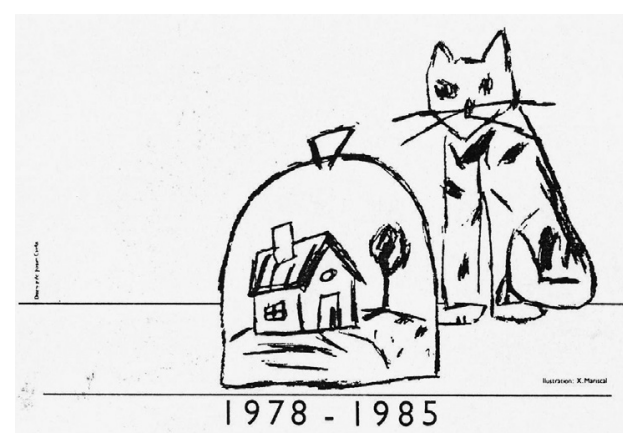

Une façon d'apprendre. Escola Tècnica Superior d'Arquitectura del Valles

Universitat Politècnica de Catalunya

Maison des Arts Plastiques Rhône-Alpes

24 Rue Etienne Rognon, Lyon

28 Mai-15 Juin

$\wedge$ Cartell del curs d'introducció a l'arquitectura i el

projecte. ETSAV, a Lió
Al director Carles Fochs per la seva entusiasta complicitat.

\section{Una petita història}

Al llarg de tot el curs 1977-78, per iniciativa i sota la direcció del professor i arquitecte Pere Riera, un equip interdisciplinari de professors va elaborar al llarg de sis mesos el programa d'una assignatura que, més enllà del seu títol oficial, responia al nom pràctic de Projectes "O" $\mathrm{i}$ tenia com a finalitat demostrar la viabilitat i la bondat d'iniciar a l'estudiant en els projectes d'arquitectura des del primer curs de la carrera. Els altres professors de l'equip eren els arquitectes D. Freixes i J.M. Gutiérrez; un dissenyador industrial, J. Mañá i un escultor, J. Pablo.

Eren altres temps, on la pràctica interdisciplinària i la collaboració de professors sense titulació oficial era possible. En aquest sentit, els coneixements del dissenyador industrial i la capacitat d'experimentació de l'escultor van ser decisius pel bon desenvolupament de l'experiència docent.

El curs 1978-79 i per primera vegada, es va dur a la pràctica el programa a l'Escola d'Arquitectura del Vallès gràcies al recolzament i la implicació de l'aleshores director de la escola Carles Fochs. La nota era compartida amb l'assignatura de dibuix per complir els requeriments legals del pla d'estudis vigent.

\section{Una síntesi conceptual}

La primera etapa del curs, "PENSAR AMB EL COS", s'inscrivia en la voluntat d'aprendre a PENSAR CONSTRUCTIVAMENT, convertint en experiència pròpia aquella precisa sentència de Jean Prouvé: "Tot objecte susceptible de ser creat, exigeix en el seu plantejament una "idea constructiva" rigorosament realitzable".

La segona i darrera etapa, "VIURE LA FESTA", s'inscrivia en la voluntat d'educar el desig aprenent a PENSAR POĖTICAMENT i entenent, de manera anàloga, que "tot objecte susceptible de ser creat. exigeix en el seu plantejament una "idea poètica" rigorosament comunicable".

S'aprenia, finalment, que ambdós tipus de plantejaments es necessiten i s'alimenten de manera permanent per acabar sent indestriables en el producte final.

La festa que cloïa el curs, organitzada al voltants dels treballs produits per una "mostra d'arquitectura ambiental i recreativa", va arribar a ser tan famosa en l'entorn de l'escola que va esdevenir una gran festa comarcal i, fins i tot, la premsa escrita i TV3 se'n van fer ressò.

\section{Dos objectius prioritaris}

El primer objectiu era canviar les condicions del "fet pedagògic". Volíem recrear els mecanismes d'aprenentatge retornant a l'estudiant el seu caràcter de productor de coneixement i deixar de considerar-lo com un agent passiu de l'ensenyament.

Per això, era necessari que la pràctica pedagògica portés a l'estudiant a descobrir primer, i a verificar després, per ell mateix, el resultat de la seva experiència mitjançant propòsits comprensibles i de complexitat creixent i progressiva. En aquest sentit, la temàtica experimental es basava en propostes que exigien una especulació constructiva-formal molt propera al discurs del disseny bàsic que, si bé per la seva manca de complexitat no eren propostes arquitectòniques completes, tenien, en canvi, un alt valor introductori en la ma en la manera de pensari formalització. En qualsevol cas, tots érem conscients de que no són dominis excloents, ans al contrari.

El segon objectiu era buscar una articulació entre assignatures capac de superar la fragmentació sistemàtica i estanca dels diversos coneixements que l'estudiant rep.

Volíem referenciar l'aprenentatge de la proposta arquitectònica en una pràctica pedagògica més unitària al seu voltant de manera que l'estudiant mai perdés de vista que totes les altres matèries que enriqueixen el currículum acadèmic i, més enllà de la seva específica autonomia disciplinar, contribueixen, garanteixen i milloren la capacitat de proposta. (Posteriorment $i$ al meu parer, una articulació errònia i confusa d'aquests postulats ha provocat molts equivocs en el desenvolupament posterior de l'ensenyament de projectes a la pròpia Escola).

\section{El decàleg pedagògic}

PENSAR AMB EL COS: pensar constructivament.

APRENENTATGE I PRODUCTE VS ENSENYAMENT I DISCIPLINA: experimentació, verificació, fruïció.

UN ESTUDIANT PRODUCTOR DE CONEIXEMENT VS UN ESTUDIANT RECEPTOR PASSIU DE CONEIXEMENT: aprendre des d'un mateix.

IMPARTIR ÉS COMPARTIR: el professor no té la veritat i tan sols es basa en la seva major experiència.

APRENDRE CONVERSANT: "do it with others vs do it yourself”. El treball col/laboratiu.

IMPUGNAR ELS CODIS ACADÈMICS I PROFESSIONALS ESTABLERTS: pensar críticament.

PENSAR HISTÒRICAMENT: antecedents i conseqüències dels processos. Aprendre del canvi.

PROBLEMATITZAR EL PRESENT: aprendre de l'actualitat, incidint sobre ella.

EDUCAR EL DESIG: pensar poèticament. El joc i la festa s'incorporen al ritme pedagògic.

\section{Els exercicis}

PLA HORITZONTAL: amb un tauler de $1.5 \mathrm{~cm}$. de gruix construir un pla horitzontal de $40 \times 40 \mathrm{~cm}$.
LA TORRE DE PAPER: a partir d'una làmina de paper de $25 \times 32.5 \mathrm{~cm}$. construir l'estructura més alta possible, sense cap additiu i amb el malbaratament mínim.

LA TORRE DE FILFERRO: amb filferro de $0.9 \mathrm{~mm}$. de gruix i fil de sedalina, construir l'estructura més alta possible capaç d'aguantar el pes d'una rajola de $15 \times 15 \times 0.5 \mathrm{~cm}$.

LA BIGA: amb canonets de plàstic de $0.5 \mathrm{~cm}$. de diàmetre i $20 \mathrm{~cm}$. de llarg i una soldadura (flama) construir amb el mínim material possible una estructura de $40 \mathrm{~cm}$. de llum capaç d'aguantar el pes d'una rajola de $15 \times 15 \times 0.5 \mathrm{~cm}$.

LA VOLADA: donats dos perfils de fusta de pi de $0.3 \times 0.3 \times 90 \mathrm{~cm}$. i fil de sedalina, collocar un pes de 30 grams el més lluny possible de la taula, utilitzant com a contrapès 9 ploms de 30 grams.

EL VESTIT: construir amb cartró ondulat, grapes i tisores una membrana protectora que cenyeixi i cobreixi el cos, amb la màxima mobilitat.

EL CONTENIDOR: construir amb el mínim material possible un element que retingui i immobilitzi una pilota de tennis, una rajola de ceràmica, un paquet de tabac $\mathrm{i}$ 250 grams de cigrons.

LA CABANA: amb 60 euros i amb 18 hores de muntatge, construir, entre deu estudiants, un espai on deu persones hi puguin passar una nit.

LA FESTA: mostra d'arquitectura ambiental i recreativa al recinte de l'Escola.

ABSTRACT

El curs 1978-79 es va posar en pràctica a l'ETSAV el programa d'una assignatura que responia al nom pràctic de Projectes "O" i que tenia com a finalitat demostrar la viabilitat i i a bonda d'iniciar a l'estudiant en els projectes d'arquitectura des del primer curs de la carrera.

La primera etapa del curs s'inscrivia en la voluntat d'aprendre a pensar constructivament; la segona part perseguia educar el desig en pensar poèticament. El curs acabava sempre amb una festa, que amb els anys es va convertir en un esdeveniment comarcal.

Els dos objectius prioritaris del curs eren el següents: retornar a l'estudiant el seu caràcter de productor de coneixement, i buscar una articulació entre assignatures capaç de superar la fragmentació dels diversos coneixements rebuts per l'estudiant.

PALABRAS CLAVE: projectes; aprenentatge; ensenyament; coneixement.

PERE RIERA es Doctor Arquitecto por la Universitat Politècnica de Catalunya y socio fundador de RGA Arquitectes desde 1982. Desde 1975 ha desarrollado una extensa labor docente en la ETSAB, la ETSAV, la escuela EINA y el BIArch. 

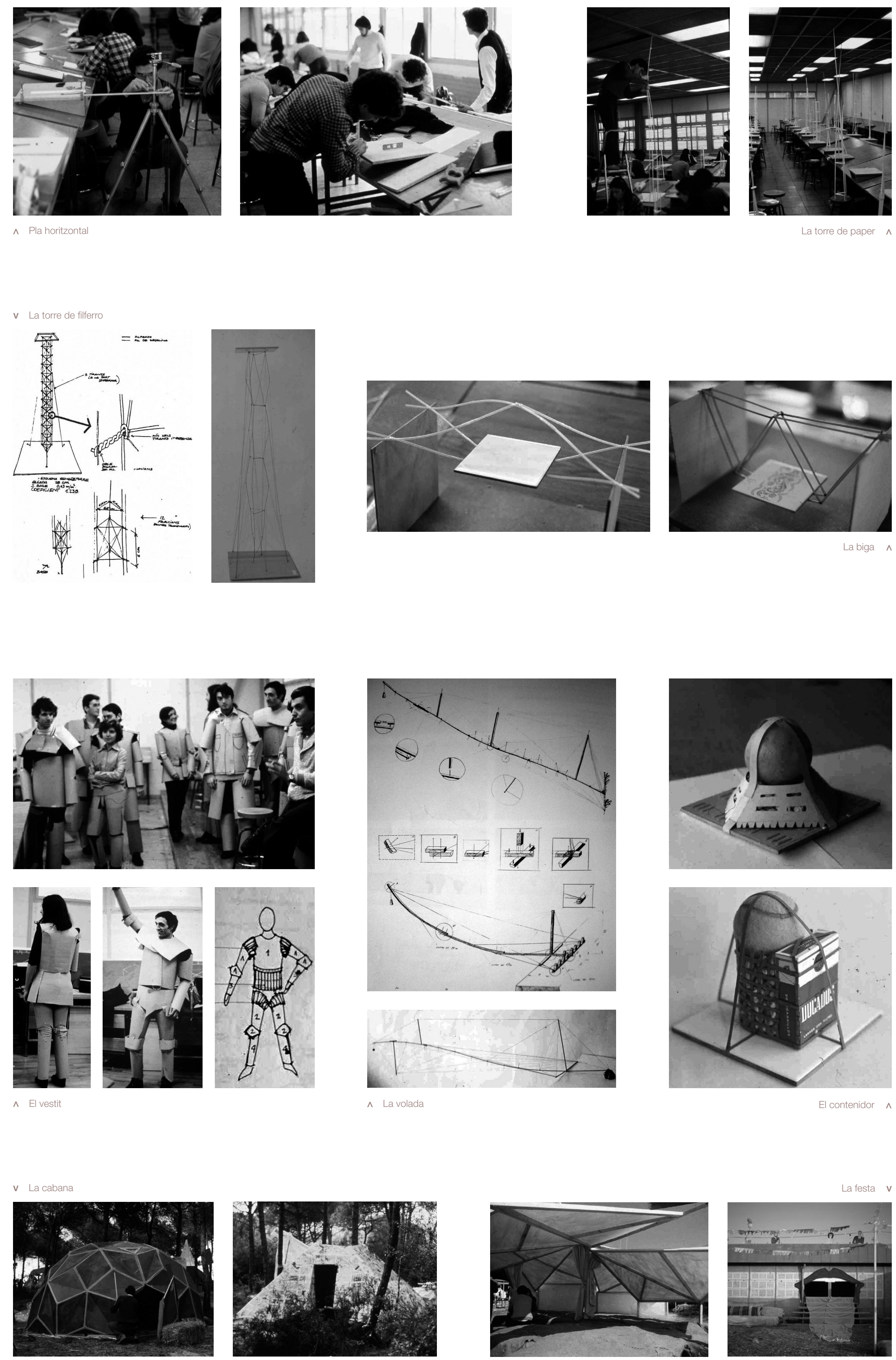